\title{
Concentration of hydroalcoholic extracts of graviola (Annona muricata L.) pruning waste by ultra and nanofiltration: Recovery of bioactive compounds and prediction of energy consumption
}

\author{
Ingrid V. M. de Moraes ${ }^{a,}{ }^{*}, 1$, Renata S. Rabelo ${ }^{\text {b, }}$, Júlia A. de L. Pereira ${ }^{\text {b }}$, \\ Miriam D. Hubinger ${ }^{\mathrm{b}}$, Flávio L. Schmidt ${ }^{\mathrm{b}}$ \\ ${ }^{a}$ Embrapa Agroindústria Tropical, Rua Dr $^{a}$ Sara Mesquita, 2270, Pici, 60511-110, Fortaleza, CE, Brazil \\ b School of Food Engineering, University of Campinas (UNICAMP), R Monteiro Lobato, 80, 13083-862, P.0. Box 6121, Campinas, SP, Brazil
}

\section{A R T I C L E I N F O}

\section{Article history:}

Received 22 June 2017

Received in revised form

15 October 2017

Accepted 9 November 2017

Available online 10 November 2017

\section{Keywords:}

Phenolic compounds

Antioxidant capacity

Membrane processes

Fouling

Soursop

Energy consumption

\begin{abstract}
A B S T R A C T
Concentrated extracts of graviola leaves, which are widely discarded during the pruning of trees in commercial crops, were obtained by different membrane concentration process. These leaves are commonly used in traditional medicine due to their pharmacological properties. In this study, hydroalcoholic extracts (with 50 or $70 \%$ of ethanol $(v / v)$ ) of graviola leaves were subjected to ultrafiltration (UF), nanofiltration (NF) and to combination of both processes (UF followed by NF). The concentrated fractions coming from these processes were analyzed for their total antioxidant capacity and total phenolic content in order to evaluate the selectivity of each concentration step. Processes performance were also evaluated for productivity (permeate fluxes) and energy consumption, which allowed the choice of the best membrane filtration system in terms of energy savings and of interest compounds retention. The combination of processes of UF and NF showed retention coefficients higher than $75 \%$ in concentration of phenolic compounds. This sequential design resulted also in higher fluxes of NF, the fluxes increased almost seven times for extracts with $50 \%$ of ethanol, and almost three times for extracts with $70 \%$ of ethanol when compared to direct processes o NF. Furthermore, the combined system of UF and NF promoted a significant reduction in the concentration time of the extracts by NF and the characterization of fouling mechanisms, which is important parameters to scale-up of this process, indicated that the strategy may increase the useful life of the membranes.
\end{abstract}

() 2017 Elsevier Ltd. All rights reserved.

\section{Introduction}

Graviola (Annona muricata L.), also known as "soursop" in English, "guanábana" in Spanish and "corossol" in French, belongs to the Annonaceae family, with about 119 genera and more than 2000 species. It is an ever green, terrestrial, erect tree that can grow to 5-8 $\mathrm{m}$, having wide and dark green leaves and a mild and bright appearance (São José et al., 2014). It is native in the tropical regions of Central America and northern regions of South America, but has been distributed throughout all tropical regions (Freitas, 2012). The state of Bahia in Brazil is the world's largest graviola producer, and despite a scarcity of data on its planted area and production, the

\footnotetext{
* Corresponding author.

E-mail address: ingrid.moraes@embrapa.br (I.V.M. Moraes).

1 These authors contributed equally to this work.
}

estimated harvest in 2012 was 20,000 tons in a planted area of about 1,570 ha (ADAB, 2016; Lemos, 2014; São José et al., 2014). Its fruits are mainly processed as juices, ice cream, jams and sweets. The peels, leaves, stems, roots and fruit seeds are also well known and widely used in traditional medicine, containing a vast variety of chemical compounds known for their medicinal properties (Gajalakshmi et al., 2012; Gavamukulya et al., 2014; Machado et al., 2015; Matos and Lorenzi, 2008).

Graviola leaves are rich in bioactive compounds and have a high antioxidant capacity. Therefore, they can be used in an array of high-value-added products, such as dietary supplements and phytotherapics. Additionally, tons of leaves and twigs are discarded annually in producing countries because pruning is an indispensable practice for harvesting the fruits quickly.

Phytochemical screening of $A$. muricata leaves extracts revealed that they are rich in secondary metabolites such as alkaloids, saponins, terpenoids, flavonoids, coumarins and lactones, 
anthraquinones, tannins, cardiac glycosides, annonaceous acetogenins, phenols and phytosterols (Gavamukulya et al., 2014; Moraes et al., 2016). The high presence of phenolic compounds confers potent antioxidant capacity to the leaves and their extracts (Nawwar et al., 2012). They can prevent the onset and/or progress of oxidative disorders, as well as reduce the risk of diseases such as cancer, arthritis, diabetes and other diseases that occur during aging (Almela et al., 2006; Tabart et al., 2007).

Recovery of phenolic compounds from plant sources such as graviola leaves is generally made using methanol, ethyl acetate, acetone or other organic solvents which can compromise the final application of the extracts in food or pharmaceutical industries (Azmir et al., 2013; Moraes et al., 2016). Thus, the use of ethanol, a recognized GRAS solvent (Generally Recognized as Safe), have been extensively explored for this application. Nevertheless, the concentration of extracts obtained by hydroalcoholic extraction usually use heat to promote solvent evaporation, this process can harm a wide variety of thermally sensitive phenolic compounds present in graviola leaves and can influenced the antioxidant capacity of their extracts (Chipurura et al., 2010).

The use of UF and/or NF polymeric membranes has been explored for many years to concentrate bioactive compounds from plant extracts (Conidi et al., 2012; Cruz et al., 2013; El-Abbassi et al., 2014; Ferrer-Polonio et al., 2017; Li and Chase, 2010; Murakami et al., 2011; Pinto et al., 2014; Prudêncio et al., 2012) and for recovering phenolic compounds from wastewater (Giacobbo et al., 2017; La Scalia et al., 2017; Romero-Dondiz et al., 2016). However, the application of these membrane processes using organic solvents such, as ethanol for example, is still a challenge (Weinwurm et al., 2016). The stability of the membranes with organic solvents is questionable and normally shows reduced permeated fluxes and high energy consumption, when compared to aqueous filtration system processes (Cassano et al., 2013; Alles et al., 2015; Cissé et al., 2011; Weinwurm et al., 2016). Thus the objective of present work is to evaluate the recovering of phenolic compounds from hydroalcoholic extracts of graviola leaves.

Although the phytochemical characteristics of graviola leaves are widely studied, to the best of our knowledge there are no reports on the concentration of bioactive compounds of graviola leaves in literature. The UF, NF and a combination of both concentration membrane processes were evaluated in order to optimize the choice of the best membrane filtration system in terms of energy saving and retention of the compounds of interest.

\section{Material and methods}

\subsection{Raw material}

Graviola ( $A$. muricata $\mathrm{L}$ ) leaves were obtained from a commercial cultivation located in the city of Trairi - CE, Brazil, latitude $3^{\circ} 22$ '15.98 "S and longitude $39^{\circ} 17^{\prime} 34.46^{\prime}$ "W. Voucher specimens are kept at Herbarium Prisco Bezerra under number 58,330, located at the Federal University of Ceará, Fortaleza, CE, Brazil. After harvesting, leaves were selected, washed and sanitized with a sodium hypochlorite solution $(100 \mu \mathrm{g} / \mathrm{mL})$ and then dried at $40^{\circ} \mathrm{C}$ for $30 \mathrm{~h}$ in a forced air dryer at Embrapa Tropical Agroindustry, Fortaleza, $\mathrm{CE}$, Brazil. Then, the leaves were ground into a powder using a knife mill and stored in metallized bags at room temperature.

The powdered graviola leaves were then sieved through a mesh 28 sieve (Tyler Standard Sieve Series - Granutest, Brazil) obtaining particles smaller than $0.6 \mathrm{~mm}$ in size. From these particles were prepared the hydroalcoholic extracts. The solid-liquid extraction was performed at a ratio of $1 \mathrm{~g}$ of sieved leaves $/ 20 \mathrm{~mL}$ of solvent in a proportion of 50 or $70 \%$ of ethanol in water $(\mathrm{v} / \mathrm{v})$. The flasks were capped to prevent solvent evaporation. The extraction was conducted in a shaker in a thermostatic bath (TE-052 Dubnoff Fibralimentar, Tecnal, Brazil) at $80 \mathrm{rpm}$ and $50{ }^{\circ} \mathrm{C}$ for $15 \mathrm{~min}$, and the extracts were then filtered through a Büchner funnel with a vacuum pump. The experimental conditions used (Ethanol/water concentrations, temperature and extraction time) were optimized from a previous study by our research group (Moraes et al., 2016), but the final work with optimization planning has not yet been published.

The ethanol (EtOH) was from LS Chemicals (Analytical grade, Purity: 99\%, Mumbai, India), while the ABTS (2,2'-azino-bis(3ethylbenzothiazoline-6-sulfonic acid)) diammonium salt, Trolox (6-hydroxy-2,5,7,8-tetramethylchroman-2-carboxylic acid), fluorescein sodium salt and Folin-Ciocalteu reagent were from Sigma Aldrich (St. Louis, MO), and potassium persulfate was from Acros Organics (Geel, Belgium).

\subsection{Ultrafiltration (UF) and nanofiltration (NF) processes}

UF and NF processes were carried out in a tangential filtration system (INVICT, MENTEST, Brazil) in a flat sheet module. The system is comprised of a jacketed stainless steel feed tank with a capacity of $1.5 \mathrm{~L}$, attached to a refrigeration unit to control process temperature, and a direct drive piston pump (Model 2SF05SEEL, Cat pump, Minneapolis, USA) for feed circulation, a valve for pressure adjustment and a pressure gauge to control the module's output pressure. The filtration unit has a rectangular shape with dimensions of $0.11 \mathrm{~m} \times 0.07 \mathrm{~m}$, making a permeation membrane area of $0.0077 \mathrm{~m}^{2}$.

The filtrations were carried out in a continuous mode where the feed solution was recirculated in the system. The fixed operational parameters were: outlet pressure: 0.7 MPa (UF) and 2.0 MPa (NF); recirculation flow: $70 \mathrm{~L} / \mathrm{h}(\mathrm{UF})$ and $60 \mathrm{~L} / \mathrm{h}(\mathrm{NF})$; operating temperature $35^{\circ} \mathrm{C}$.

The processes were interrupted when the volume concentration factor (VCF) achieved 2.0 (UF) and 1.7 (NF). These VCF were defined based on the maximum process time of $6 \mathrm{~h}$ for UF and $8 \mathrm{~h}$ for NF. All experiments were performed in duplicate and the results were expressed as the average between them. Feed, permeate and concentrate stream samples were taken for further analysis of total phenolic (TP) content and antioxidant capacity (AC) and evaluation of the retention of these compounds. The amount of permeate that passes through the membrane in a given time was also registered to calculate the permeate flux.

The membranes were pre-conditioned by soaking them in ethanol/water solution (50 or $70 \%$ of ethanol in water $(\mathrm{v} / \mathrm{v})$ depending on the process) for $16 \mathrm{~h}$ at room temperature. This step aims to improve the permeate flux, thus ensuring that the membrane was thoroughly wetted by the solvent, which facilitates permeation. The main specifications of the membranes used are shown in Table 1.

Both membranes have hydrophilic characteristics and a good mechanical strength. The NF270 is a thin film composite membrane where the upper layer is of polyamide and the thicker bottom layer is of polysulfone. This membrane was used with the purpose of retaining the phenolic compounds of the graviola leaves that have a molar mass between 300 and $600 \mathrm{~g} / \mathrm{mol}$. The UH004 membrane was chosen due to its good permeability and ability to retain macromolecules by promoting partial purification of the extract prior to NF.

\subsection{Schematic design of processes}

The membrane filtration processes were carried out as shown 
Table 1

Specifications of ultra and nanofiltration membranes used in the experiments.

\begin{tabular}{|c|c|c|}
\hline Parameters & UH004 & NF270 \\
\hline Manufacturer & Microdyn-Nadir ${ }^{\mathrm{a}}$ & DOW FILMTEC ${ }^{\mathrm{b}}$ \\
\hline Material $^{\mathrm{j}}$ & PESH & Polyamide thin-film composite \\
\hline $\operatorname{MWCO}(\mathrm{g} / \mathrm{mol})^{\mathrm{j}}$ & 4.000 & $200-300$ \\
\hline Pore size (nm) & $1.075^{\mathrm{c}}$ & $0.84^{\mathrm{d}}$ \\
\hline $\mathrm{T}^{\mathrm{MO}}\left({ }^{\circ} \mathrm{C}\right)^{\mathrm{j}}$ & 95 & 45 \\
\hline $\mathrm{P}^{\mathrm{MO}}(\mathrm{MPa})^{\mathrm{j}}$ & 1.0 & 4.1 \\
\hline $\mathrm{pH}^{\mathrm{j}}$ & $0-14$ & $3-10$ \\
\hline Retention (\%) & $92-99^{\mathrm{e}}, \mathrm{h}$ & $>97^{\mathrm{f}}, \mathrm{i}$ \\
\hline Permeability to pure water $\left(\mathrm{kg} /\left(\mathrm{m}^{2}\right.\right.$. h.bar $\left.)\right)$ & $>7^{\mathrm{i}}$ & $17^{\mathrm{g}}$ \\
\hline Membrane thickness $(\mu \mathrm{m})^{\mathrm{k}}$ & $120-130$ & $210-250$ \\
\hline
\end{tabular}

MWCO (g/mol): Molecular weight cut-off, $\mathrm{T}^{\mathrm{MO}}\left({ }^{\circ} \mathrm{C}\right)$ : Maximum operating temperature, $\mathrm{P}^{\mathrm{MO}}$ (MPa): Maximum operating pressure, PESH: Polyethersulphone with hydrophilic treatment, ${ }^{a}$ Wiesbaden, Germany, ${ }^{b}$ Illinois, USA, ${ }^{\mathrm{c} O a t l e y-R a d c l i f f e}$ et al. (2015), ${ }^{\mathrm{d}} \mathrm{Nghiem}$ and Hawkes (2007), ${ }^{\mathrm{e}}$ Mohammad et al. (2015), ${ }^{\mathrm{f}}$ Penha et al. (2015), ${ }^{\mathrm{g}}$ Cissé et al. (2011), hetention of $\mathrm{MgSO}_{4}, 2000 \mathrm{mg} / \mathrm{L}$ at $25^{\circ} \mathrm{C}$, ${ }^{\mathrm{i}}$ Retention of Dextran at $25{ }^{\circ} \mathrm{C}$, ${ }^{\mathrm{j}} \mathrm{Data}$ of Manufacturer, ${ }^{\mathrm{k}}$ Data experimentally obtained.

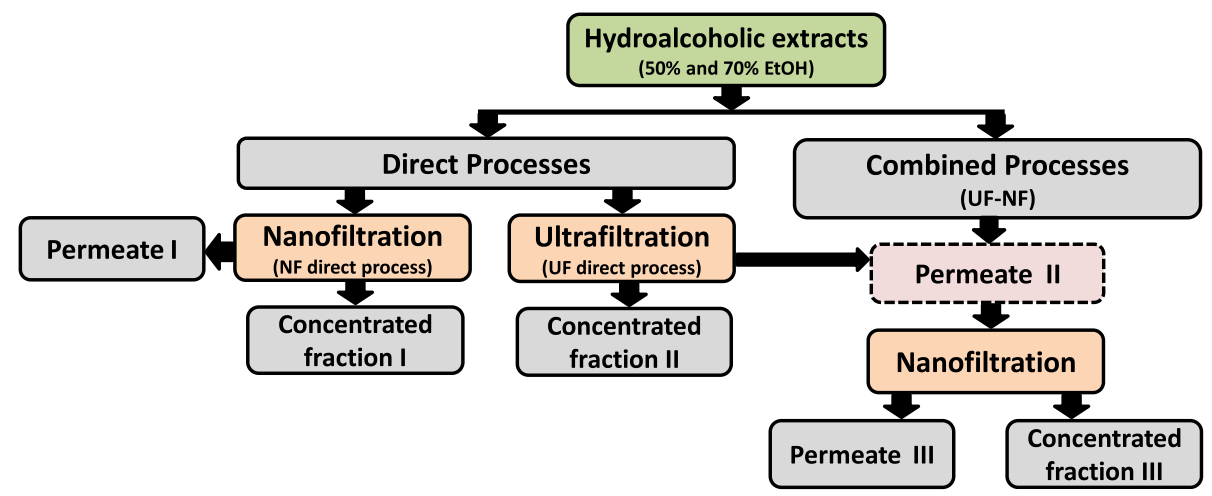

Fig. 1. Schematic diagram of filtration of hydroalcoholic extracts obtained from graviola leaves concentrated by UF, NF or by sequential process (UF-NF).

by the schematic diagram (Fig. 1). Briefly, UF and NF processes were firstly carried out separately (Direct Processes). In a second moment, a sequential membrane process using UF and NF was evaluated in order to concentrate the phenolic compounds from graviola extract. In this case, the UF was carried out for suspended solids reduction. In sequence, the permeate of UF was used as feed in a NF process, that was developed in order to concentrate the compounds that permeated of the UF membrane.

\subsection{Process parameters}

\subsubsection{Determination of volumetric permeate flux $\left(J_{v}\right)$}

Volumetric permeate flux $\left(J_{v}\right)$ measured in $\mathrm{L} /\left(\mathrm{m}^{2} \mathrm{~h}\right)$, is defined as the amount of permeate that passes through the membrane area in a given time, as expressed in Equation (1), where: $m_{p}$ is the permeate collected mass $(\mathrm{g}) ; \rho$ is the solution density $(\mathrm{g} / \mathrm{L}), t$ is the time (h), and $A_{p}$ is the membrane permeation area $\left(\mathrm{m}^{2}\right)$.

$J_{v}=\frac{m_{p}}{\rho \cdot t \cdot A_{p}}$

The average permeate flux corresponds to the slope of the straight line described by the equation $V_{p}=f\left(A_{p} \times t\right)$ (Tylkowski et al., 2010).

\subsubsection{Flux decrease (\%)}

The percentual flux decrease $\left(D_{f}\right)$ was calculated according to Equation (2), where $J_{i}$ is the initial and $J_{s}$ is the average permeate flux in $\mathrm{L} /\left(\mathrm{m}^{2} \mathrm{~h}\right)$.

$$
D f=\frac{(J i-J s)}{J i} \cdot 100
$$

\subsubsection{Fouling index (b)}

The fouling index was estimated according to Equation. (3), described by Cheryan and Merin (1981):

$J=J_{0} \cdot t^{-b}$

Where $J$ and $J_{0}$ are the actual and initial permeate fluxes, $t$ is time and $b$ is the fouling index.

\subsubsection{Volumetric concentration factor (VCF)}

Volumetric concentration factor (VCF) was determined by Equation (4), where $V_{o}$ and $V_{f}$ are the initial and the final feed volumes (L), respectively.

$\mathrm{VCF}=\frac{V_{o}}{V_{f}}$

\subsubsection{Retention coefficient $(R)$}

Retention coefficient (R), expressed in \%, for total phenolics (TF) and antioxidant capacity (AC) measured by ABTS and ORAC methods were determined according to Equation (5), where $C_{p, i}$ is the concentration of solute $i$ present in the permeate and $C_{f, i}$ is the concentration of solute $i$ in the feed solution. 
$R(\%)=\left(1-\frac{C_{p, i}}{C_{f, i}}\right) 100$

\subsubsection{Energy consumption (E)}

Equation (6) was used to estimate the energy consumption $(E)$ of the processes in $\mathrm{kWh} / \mathrm{m}^{3}$ (or $0.001 \mathrm{kWh} / L$ ), as described by Jönsson and Wallberg (2009), where: $\Delta p$ is the transmembrane pressure in $\mathrm{kPa}, Q_{\text {feed }}$ is the feed recirculation flow in $\mathrm{m}^{3} / \mathrm{h}, \eta$ is the pump efficiency factor (0.95), $J_{v}$ is the volumetric permeate flux in $\mathrm{m}^{3} /\left(\mathrm{m}^{2} \mathrm{~h}\right)$ or and $A_{p}$ is the membrane area in $\mathrm{m}^{2}$.

$E=\frac{\Delta p \cdot Q_{\text {feed }}}{\eta \cdot J_{v} \cdot A}$

\subsection{Extract characterization}

\subsubsection{Total phenolic concentration}

The concentration of total phenolic compounds was determined as described by Singleton et al. (1999), with slight modifications. First, $2.5 \mathrm{~mL}$ of the Folin-Ciocauteau reagent was added to $0.5 \mathrm{~mL}$ of sample extract. After $5 \mathrm{~min}, 2 \mathrm{~mL}$ of sodium carbonate solution $(7.5 \% \mathrm{w} / \mathrm{v})$ was added, followed by mixing in a shaker tube for $10 \mathrm{~s}$. After $2 \mathrm{~h}$ protected from light at room temperature, the sample was read in an absorbance of $760 \mathrm{~nm}$ using a model DU70 UV/Vis spectrophotometer (Beckman Instruments, Inc., Fullerton, CA, USA). A six point calibration curve was constructed using gallic acid concentrations from 8 to $72 \mu \mathrm{g} \mathrm{mL}{ }^{-1}$. Results were expressed in $\mathrm{mg}$ of gallic acid equivalent per $\mathrm{g}$ of dry extract, and were expressed as average \pm standard deviation (three replicates).

\subsubsection{Antioxidant capacity}

The antioxidant capacity of extract fractions was evaluated by two different methods based on distinct mechanisms. The first involved the transfer of electrons (ABTS) using Free Radical Capture $\mathrm{ABTS}^{+}$, according to the methodology described by Rufino et al. (2007), and quantified according to Re et al. (1999). The second was based on hydrogen transfer (Oxygen Radical Absorbance Capacity-ORAC), according to the methodology described by Dávalos et al. (2004) with slight modifications. The results were expressed as Trolox Equivalent Antioxidant Capacity (TEAC) per g of dry extract.

\subsubsection{Particle size distribution}

Particle size distribution of the extracts was determined by laser diffraction in a Laser Scattering Mastersizer (Malvern Instruments, Mastersizer 2000 UK). Diameter was determined based on the average diameter of a sphere with the same volume (Brouckere Diameter $-\mathrm{D}_{43}$ ). All samples were analyzed three times.

\subsection{Characterization of the membranes}

\subsubsection{Atomic force microscopy (AFM)}

Analysis of the membranes' surface morphology was done before and after the concentration process. Membranes were analyzed using an atomic force microscope (AFM) NanoSurf model EasyScan 2 (Liestal, Switzerland). The scanning was performed on a membrane surface area of $75 \mu \mathrm{m} \times 75 \mu \mathrm{m}$ in non-contact mode, and the images were processed using free Gwyddion software version 2.43 (Czech Metrology Institute, Czech Republic), which provided the parameters related to sample roughness. After acquiring each original membrane image, new images with a side length of $5,10,22$, and $41 \mu \mathrm{m}$ were obtained. Roughness mean square values (Rms) were obtained from the photomicrographs.

\subsection{Statistical analysis}

All the results were submitted to analysis of variance (ANOVA) and Tukey test was used to compare the means obtained from the membrane concentration processes. SAS software version 9.4 (SAS Institute Inc, USA) was used to perform the analysis. Differences were considered significant at a level of $5 \%(p \leq 0.05)$. Mathematical modeling was performed with Statistica 8.0 (Statsoft, USA) in order to evaluate fouling mechanisms.

\section{Results and discussion}

\subsection{Feed characterization}

Moisture, ash, total protein, lipids, carbohydrates, solids, $\mathrm{pH}$, density and antioxidant capacity extract values are shown in Table 2 . The extract with $70 \%$ EtOH contained a higher amount of lipids and proteins than the one with $50 \% \mathrm{EtOH}$, which on the other hand showed a greater amount of ash and carbohydrates. This is reasonable since fats are hydrophobic, while carbohydrates and metals that result in ash are hydrophilic. The obtained higher protein content using more EtOH suggests that most of the recovered proteins were lipophilic, being membrane-bound proteins. It should be noted that proteins and enzymes are denatured by EtOH, causing suspended particles to form. These suspended particles had their size distribution determined and the results are presented in Fig. 2(see Table 3).

The extracts with $50 \%$ EtOH showed a smaller particles size distribution, whereas the particles dispersed in extracts with 70\% EtOH were larger and the particle size distribution graph still showed a bimodal profile with a second well-marked peak with particles around $500 \mu \mathrm{m}$, which was not observed for the extract with $50 \% \mathrm{EtOH}$. The increase of ethanol percentage in the extract may have favored particle agglomeration.

According to Rabelo et al. (2016) this can happen because in polar solvents the suspended macromolecules in the extracts are generally electrostatically more stable and less susceptible to agglomeration or precipitation. Once the polarity is reduced by an increase on ethanol concentration, a greater destabilization of the system occurs, favoring cluster formation. This explanation suggests that the extract containing $70 \% \mathrm{EtOH}$ is the most likely to form clusters and promote fouling.

\subsection{Direct process(UF and NF) of membrane concentration}

\subsubsection{Retention of bioactive compounds}

Differences in composition of total phenolic compounds and also in antioxidant capacity between feed, concentrate and permeate were significant ( $\mathrm{p} \leq 0.001$ ) for the two evaluated process (UF and NF) and for both extracts (50 and 70\% EtOH), indicating the good retention of evaluated membranes. However, in case of UF, the retention coefficients related to ABTS and ORAC are nearly independent on the percentage of $\mathrm{EtOH}$. Similar behavior was observed to NF membranes considering the total phenolic compounds (TP) and ABTS. These results may be associated with the fact that these membranes, regardless of the solvent composition or the filtration process evaluated, have formed a cake layer on their surface during the filtration process that contributed to a very close retention of phenolic compounds.

Finally, comparing the processes was observed that NF showed higher retention coefficients compared to UF, as expected. 
Table 2

Characteristics of hydroalcoholic extracts from graviola leaves with $50 \%$ and $70 \% \mathrm{EtOH}(\mathrm{v} / \mathrm{v})$.

\begin{tabular}{lll}
\hline Parameters & Feed 50\% EtOH & Feed 70\% EtOH \\
\hline Moisture (g/100 g, w.b.) & $98.7 \pm 0,5$ & $98.6 \pm 0,7$ \\
Ash (g/100 g, d.b.) & $14.6 \pm 1$ & $11.6 \pm 0.9$ \\
Protein (g/100 g, d.b.) & $7.2 \pm 1.7$ & $10.2 \pm 1.6$ \\
Lipids (g/100 g, d.b.) & $15.4 \pm 0.9$ & $21.7 \pm 1.1$ \\
Carbohydrates (g/100 g, d.b.) & $37.7 \pm 1.9$ & $29.7 \pm 1.6$ \\
\hline Total solids (g/100 g, w.b.) & $1.3 \pm 0.1$ & $1.4 \pm 0.1$ \\
pH & $6.1 \pm 0.0$ & $6.0 \pm 0.0$ \\
Density (g/cm ${ }^{3}$ ) & $0.93 \pm 0.01$ & $0.89 \pm 0.01$ \\
Total phenolics (mg GAE/g, d.b.) & $166.4 \pm 8.9$ & $132.8 \pm 9.8$ \\
Antioxidant capacity ABTS $(\mu \mathrm{mol}$ TEAC/g, d.b.) & $1516.0 \pm 82.0$ & $1088.4 \pm 90.8$ \\
Antioxidant capacity ORAC $(\mu \mathrm{mol}$ TEAC/g, d.b.) & $9256.1 \pm 220.1$ & $8683.8 \pm 213.5$ \\
\hline
\end{tabular}

Data presented corresponds to an average of three determinations. w.b. = wet basis, d.b. = dry basis.

Table 3

Retention coefficients of bioactive compounds of nano (NF) and ultrafiltration (UF) direct processes of hydroalcoholic extracts from graviola leaves with $50 \%$ and $70 \%$ of $\mathrm{EtOH}(\mathrm{v} / \mathrm{v})$.

\begin{tabular}{llll}
\hline Direct process & \multicolumn{4}{l}{ Retention coefficients } \\
\cline { 2 - 4 } & TP $(\%)$ & ABTS $(\%)$ & ORAC (\%) \\
\hline NF 50\% EtOH & $97.9 \pm 0.1^{\mathrm{A}}$ & $97.1 \pm 0.3^{\mathrm{A}}$ & $96.5 \pm 0.1^{\mathrm{A}}$ \\
NF 70\% EtOH & $94.2 \pm 3.2^{\mathrm{AB}}$ & $95.8 \pm 0.7^{\mathrm{A}}$ & $91.8 \pm 0.8^{\mathrm{B}}$ \\
\hline UF 50\% EtOH & $87.3 \pm 0.4^{\mathrm{B}}$ & $86.8 \pm 0.6^{\mathrm{B}}$ & $77.4 \pm 2.0^{\mathrm{C}}$ \\
UF 70\% EtOH & $75.1 \pm 0.7^{\mathrm{C}}$ & $86.8 \pm 1.0^{\mathrm{B}}$ & $77.2 \pm 0.6^{\mathrm{C}}$ \\
\hline
\end{tabular}

Values followed by the same letter in the same column are not significantly different at $\mathrm{p} \leq 0.05$. TP $=$ Total phenolics. ABTS (2,2'-azino-bis(3-ethylbenzothiazoline-6sulphonic acid)) and ORAC (Oxygen Radical Absorbance Capacity) = antioxidant capacity measure methods.

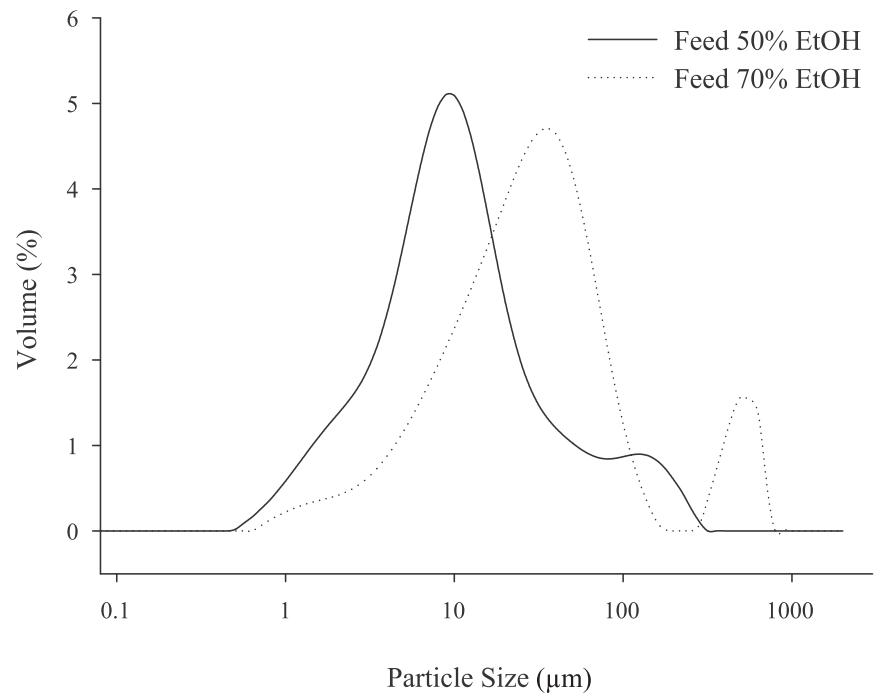

Fig. 2. Particle size distribution of the feed extracts with $50 \%$ and $70 \%$ of ethanol.

Nevertheless, the high retention coefficients (above 75\%) observed in the UF processes surprised us, since the compounds of interest in this work have a molecular mass between 100 and $700 \mathrm{~g} / \mathrm{mol}$. This is much smaller than the molecular mass cut-off of the membrane used $(4,000 \mathrm{~g} / \mathrm{mol})$. This can be explained because phenolic compounds, which are responsible for antioxidant capacity, can be strongly bound to macromolecules found in a biological matrix, especially complex carbohydrates, thus hindering their passage through the membrane pores.

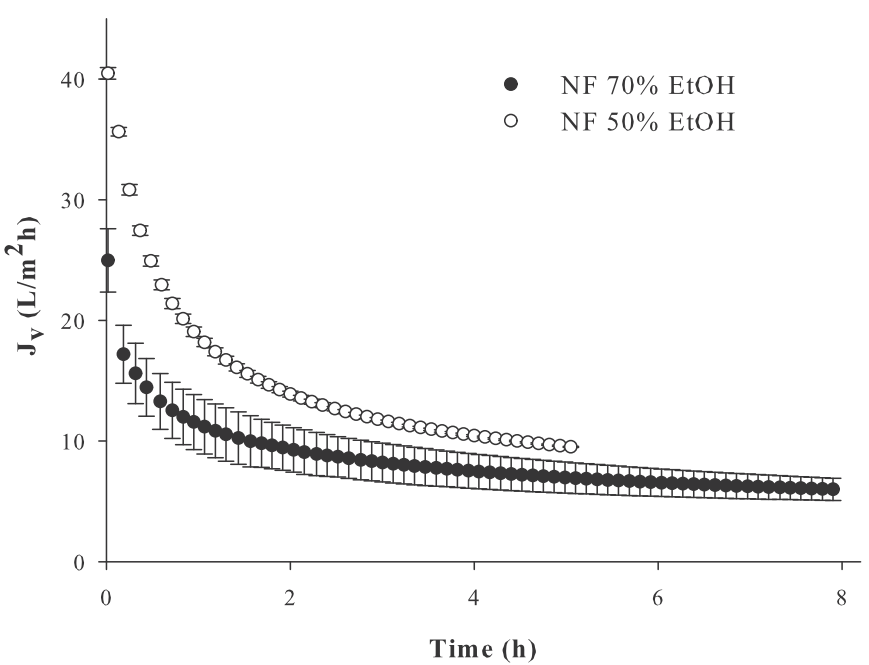

(a)

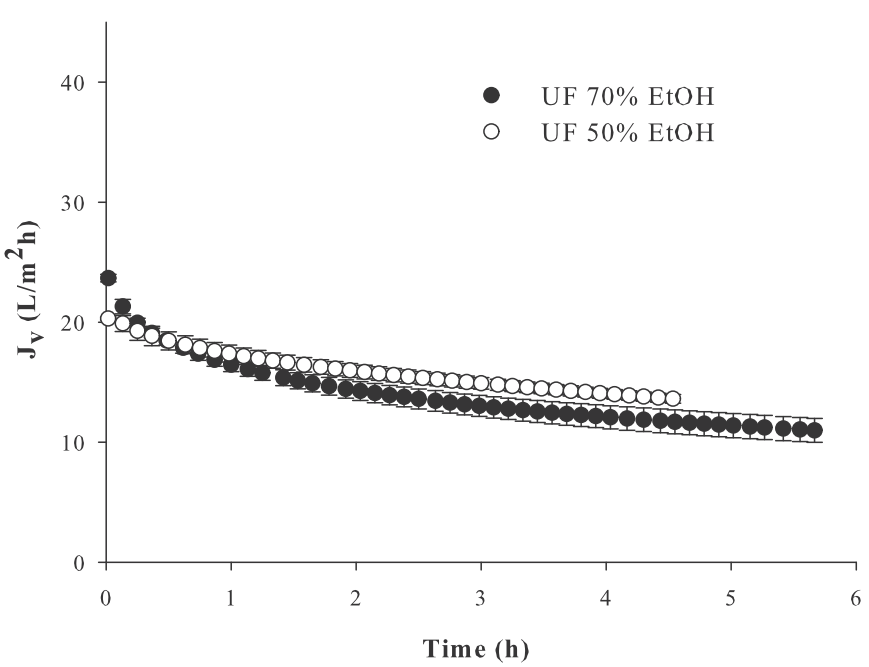

(b)

Fig. 3. Permeate fluxes of direct nanofiltration $(3 a, V C F=1.7)$ and ultrafiltration $(3 b$ $\mathrm{VCF}=2.0$ ) processes of extracts with $50 \%$ and $70 \%$ ethanol.

\subsubsection{Permeate flux evaluation}

Permeate flux curves in function of time (with standard deviations) are shown in Fig. 3(a) and (b).

The permeate flux profile obtained in UF (Fig. $3 b$ ) presented a 
Table 4

Permeate fluxes evaluation and fouling index (FI) estimation of nano (NF) and ultrafiltration (UF) direct processes of hydroalcoholic extracts from graviola leaves with $50 \%$ and $70 \%$ of EtOH (v/v).

\begin{tabular}{|c|c|c|c|c|}
\hline \multirow[t]{2}{*}{ Direct process } & \multicolumn{2}{|l|}{ Permeate fluxes } & \multicolumn{2}{|c|}{$\begin{array}{l}\text { Fouling Index } \\
\text { Estimation (FI) }\end{array}$} \\
\hline & Average (L/h.m²) & Decline (\%) & $\overline{\mathrm{FI}}$ & $\mathrm{R}^{2}$ \\
\hline NF 50\% EtOH & $7.1 \pm 0.0^{C}$ & $82.5 \pm 0.3^{\mathrm{A}}$ & 0.2719 & 0.99 \\
\hline NF 70\% EtOH & $5.4 \pm 1.0^{\mathrm{D}}$ & $80.2 \pm 5.3^{\mathrm{A}}$ & 0.3106 & 0.96 \\
\hline UF 50\% EtOH & $12.1 \pm 0.0^{\mathrm{A}}$ & $40.4 \pm 0.4^{C}$ & 0.1089 & 0.93 \\
\hline UF $70 \%$ EtOH & $9.9 \pm 0.2^{\mathrm{B}}$ & $57.9 \pm 0.5^{\mathrm{B}}$ & 0.1671 & 0.98 \\
\hline
\end{tabular}

Values followed by the same letter in the same column are not significantly different at $\mathrm{p} \leq 0.05$.

smooth decline in comparison with NF. This result can also be observed in Table 4 when evaluating the percentage decline of permeate flux, and this profile suggests that a reduced number of particles were dragged into the UF membrane surface during the filtration process, which had a markedly less effect of concentration polarization and of fouling than the NF membranes (Table 4, fouling index). This behavior was already expected since the pressure applied to UF membranes is much lower than that applied to NF membranes.

In evaluating Table 4, the processes performed with the extracts containing 50\% EtOH exhibited higher fluxes than those with 70\% $\mathrm{EtOH}$. The fact that hydrophilic membranes present higher fluxes with polar solvents is already well described in the literature (Yang et al., 2001; Bhanushali et al., 2001), but in the case of this study this fact was not the only reason to cause the observed difference, as it is possible to remark that the extracts with $70 \%$ EtOH were also the ones that presented the highest fouling index for both process (NF and UF).

The fouling index measured in this work leads us to believe that particulate matter of the feed solution had great influence on the membrane fouling mechanisms. The extract with 50\% EtOH produced smaller particles (around $10 \mu \mathrm{m}$ ) than extraction with $70 \%$ EtOH (around $35 \mu \mathrm{m}$ and $500 \mu \mathrm{m}$ ) (Fig. 2). Larger particles can increase fouling by cake formation, making the concentration difficult and reducing the flux. The effect of these bunched factors can be clearly evidenced by applying Hermia's blocking models (Hermia, 1982) (Tables 1 and 2 - Supplementary material) to predict fouling mechanisms. The analyses show that all fouling mechanisms were present during the UF and NF processes, and were dominated by cake formation, which showed the best fit $\left(\mathrm{R}^{2}=0.99\right)$, followed by intermediate, standard and complete blocking of the pores.

\subsubsection{Topography of membranes - AFM}

Atomic force microscopy (AFM) was used to analyze the surface topography of the membranes. Fig. 4(a) and (b) show the variation of Mean Square Roughness (Rms) with the scale length (L) for the membranes before and after processes. Virgin membranes were conditioned in the same way as those used in filtrations.

It is important to emphasize that roughness is a measure that is directly linked to the scale; it means that the higher the scanned areas higher are roughness values (Boussu et al., 2005, 2007; Wong et al., 2009). Smaller areas of 5, 10, 22 and $41 \mu \mathrm{m}^{2}$ were analyzed from the images of a scanned area of $75 \mu \mathrm{m}^{2}$.

NF and UF membranes had a roughness increase after processes (Fig. 4a and b), which is characteristic of the particles and aggregates' deposition on the membrane surfaces. There were not significant differences between membrane roughness for UF direct processes when $50 \%$ or $70 \%$ EtOH extracts were used. For NF, membrane roughness used in the filtration process of extracts with

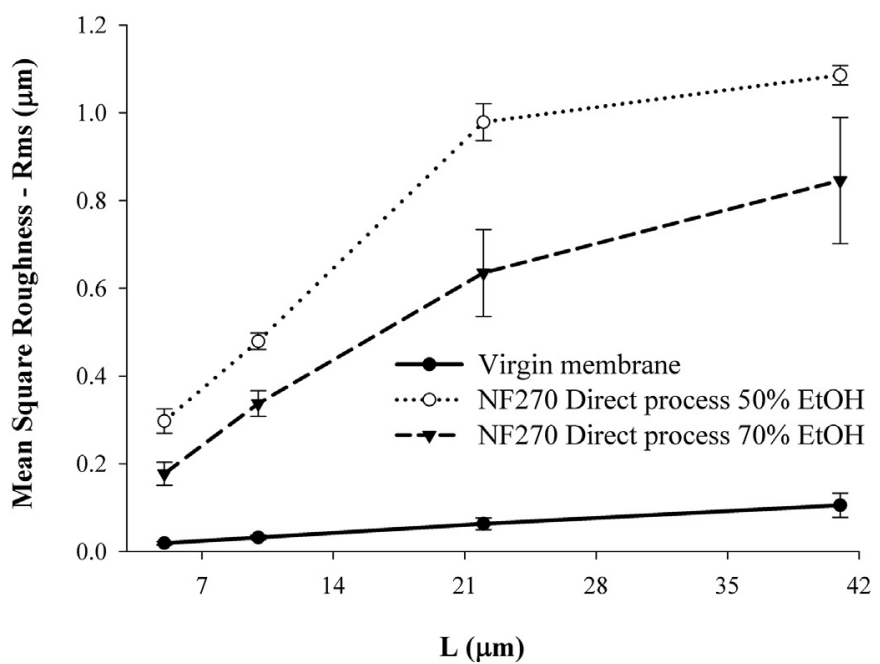

(a)

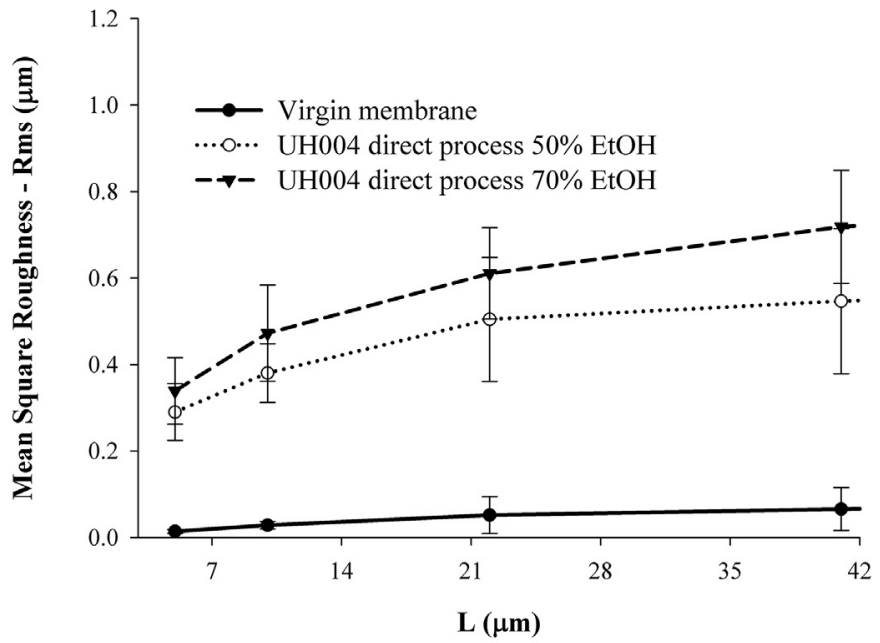

(b)

Fig. 4. Mean square roughness (Rms) as a function of the scale length $\mathrm{L}$ (side of the scanned area in $\mu \mathrm{m}$ ) of NF (4a) and UF (4b) membranes, before and after filtration processes of extracts with $50 \%$ and $70 \%$ of ethanol.

$70 \%$ EtOH was significantly higher than those used in the process with $50 \% \mathrm{EtOH}$. This is highly correlated to the greater fouling and lower permeate flux observed for processes with $70 \% \mathrm{EtOH}$.

\subsection{Combined process (UF-NF) of membrane concentration}

Considering the possibility of obtaining a faster and more economic filtration process in this step of the work, the permeate stream of UF was concentrated by NF (UF-NF process). At first, differences in permeate fluxes and in compound retention related to the ethanol concentration in the extracts were evaluated. Then, different values of working pressure were evaluated from this result.

\subsubsection{Permeate flux and retention coefficients}

The permeate fluxes of NF after UF were much higher than those observed in the direct NF processes (Fig. 5). When compared to direct filtrations, the average flux increased almost seven times for extracts with $50 \%$ EtOH, from 7.09 to $48.79 \mathrm{~L} \mathrm{~h}^{-1} \cdot \mathrm{m}^{-2}$, and almost three times for extracts with $70 \% \mathrm{EtOH}$, from 5.38 to 15.78 $\mathrm{L} \mathrm{h}^{-1} \cdot \mathrm{m}^{-2}$.

The best fluxes and retentions were obtained for the extracts 


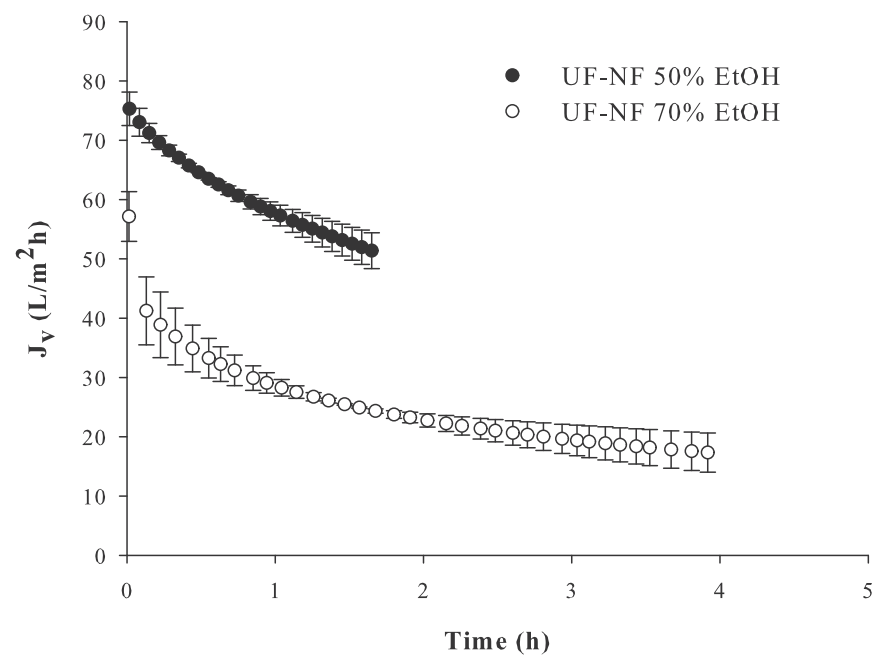

Fig. 5. Permeate fluxes of NF performed after UF (VCF $=2.3,2 \mathrm{MPa})$ of the extracts with $50 \%$ and $70 \%$ ethanol as a function of time.

with 50\% EtOH (Table 5). The average flux for extracts with 50\% EtOH was more than 3 times higher than those with 70\% EtOH. As stated earlier, the highest alcohol concentration in the extracts negatively affected the membrane filtration performance, increasing filtration time.

Regarding the retention coefficients (Table 5), firstly is important to highlight that the retention of bioactive compounds in the direct NF processes was significantly higher $(\mathrm{p} \leq 0.05)$ than in the combined processes. Since the extracts feed into the system were previously ultrafiltered, there was not very much organic material being deposited on the membrane surface as was observed in the case of direct processes, in which cake formation contributed to a greater retention of the active compounds present in the matrix.

Still, it is possible to observe that there were not significant differences in total phenolic or antioxidant capacity measured by ORAC for the different extracts according to Student's t-test at $\mathrm{p} \leq 0.05$. However, the retention observed for extracts containing $50 \%$ EtOH for antioxidant capacity measured by ABTS was significantly higher, considering the same significance level (Table 5).

A higher retention of phenolic compounds in more less

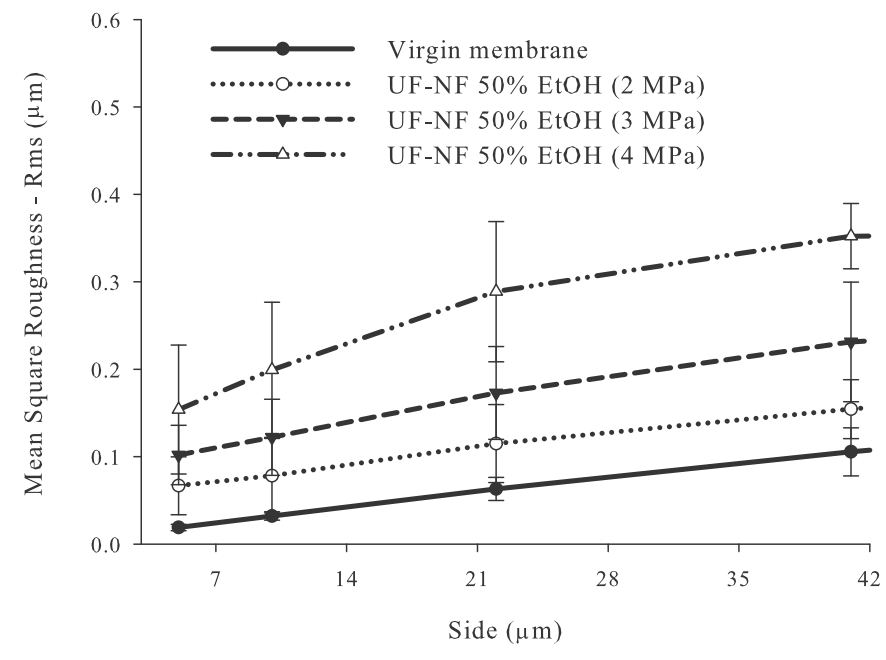

Fig. 6. Mean square roughness (Rms) as a function of the scale length $\mathrm{L}$ (side of the scanned area in $\mu \mathrm{m}$ ) of the NF membranes before and after the UF-NF process of extracts with $50 \% \mathrm{EtOH}$ at 2, 3 and $4 \mathrm{MPa}$.

concentrations of ethanol was also observed in others studies (Pinto et al., 2014; Rabelo et al., 2016; Machado et al., 2013; Geens et al., 2005) which highlight the lower membrane solvation by EtOH when compared to water, causing a greater opening of pores, and resulting in lower retention of the compounds when this solvent is used in filtration with polymeric membranes of a hydrophilic nature. However, in this study, this evidence cannot be verified because only one of the three evaluated responses presented a significant difference between hydroalcoholic extracts with different concentrations of EtOH.

Other important information we can observe during filtration process was that EtOH rejection was not observed in any of evaluated experiment, which is in agreement with the results observed by Weinwurm et al. (2016).

\subsubsection{Pressure variation}

Trials were performed under 2, 3 and $4 \mathrm{MPa}$ in order to establish the best operating pressure in NF step of combined processes. The permeate fraction from the UF process with $50 \% \mathrm{EtOH}$ (extract that shows highest fluxes) were used as feed.

Table 5

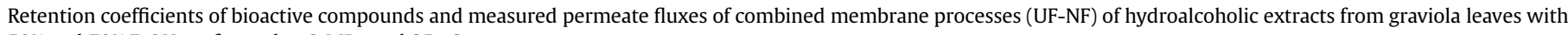
$50 \%$ and $70 \%$ EtOH performed at $2 \mathrm{MPa}$ and $35^{\circ} \mathrm{C}$.

\begin{tabular}{|c|c|c|c|c|c|c|}
\hline \multirow[t]{2}{*}{ Combined process UF-NF } & \multicolumn{3}{|l|}{ Permeate fluxes } & \multicolumn{3}{|c|}{ Retention coefficients } \\
\hline & Initial (L/h.m²) & Average (L/h.m ${ }^{2}$ ) & Decline (\%) & $\mathrm{TP}(\%)$ & ABTS (\%) & ORAC (\%) \\
\hline $50 \% \mathrm{EtOH}$ & $75.3 \pm 2.8$ & $48.8 \pm 5.2$ & $35.0 \pm 9.4$ & $77.6 \pm 1.0$ & $87.0 \pm 0.6$ & $74.9 \pm 10.6$ \\
\hline $70 \% \mathrm{EtOH}$ & $57.1 \pm 9.2$ & $15.8 \pm 4.1$ & $64.6 \pm 3.6$ & $76.3 \pm 4.6$ & $59.8 \pm 4.2$ & $70.4 \pm 2.8$ \\
\hline
\end{tabular}

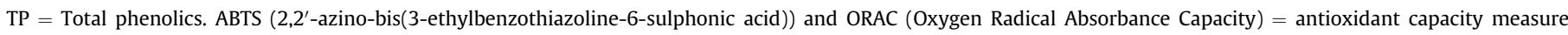
methods.

Table 6

Retention coefficients of bioactive compounds and permeate fluxes of hydroalcoholic extracts from graviola leaves with $50 \%$ EtOH performed at 2 , 3 and $4 \mathrm{MPa}$, at $35{ }^{\circ} \mathrm{C}$.

\begin{tabular}{|c|c|c|c|c|c|c|}
\hline \multirow[t]{2}{*}{$50 \% \mathrm{EtOH}$} & \multicolumn{3}{|c|}{ Retention coefficients } & \multicolumn{3}{|l|}{ Permeate fluxes } \\
\hline & $\mathrm{TP}(\%)$ & ABTS (\%) & ORAC (\%) & Initial (L/h.m²) & Average (L/h.m $\left.{ }^{2}\right)$ & Decline (\%) \\
\hline $2 \mathrm{MPa}$ & $77.6 \pm 1.0^{\mathrm{A}}$ & $87.0 \pm 0.6^{\mathrm{A}}$ & $74.9 \pm 10.6^{\mathrm{A}}$ & $75.3 \pm 2.8^{B}$ & $48.8 \pm 5.2^{\mathrm{B}}$ & $35.0 \pm 9.4^{\mathrm{A}}$ \\
\hline $3 \mathrm{MPa}$ & $78.4 \pm 1.2^{\mathrm{A}}$ & $86.3 \pm 0.0^{A}$ & $78.5 \pm 0.1^{\mathrm{A}}$ & $92.8 \pm 4.2^{\mathrm{AB}}$ & $66.4 \pm 0.4^{\mathrm{A}}$ & $28.4 \pm 3.7^{A}$ \\
\hline $4 \mathrm{MPa}$ & $79.8 \pm 0.5^{\mathrm{A}}$ & $87.1 \pm 0.2^{\mathrm{A}}$ & $77.8 \pm 0.2^{\mathrm{A}}$ & $109.0 \pm 0.9^{\mathrm{A}}$ & $70.0 \pm 1.5^{\mathrm{A}}$ & $35.8 \pm 0.9^{\mathrm{A}}$ \\
\hline
\end{tabular}

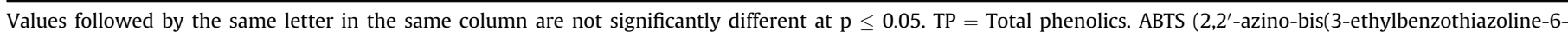
sulphonic acid)) and ORAC (Oxygen Radical Absorbance Capacity) = antioxidant capacity measure methods. 


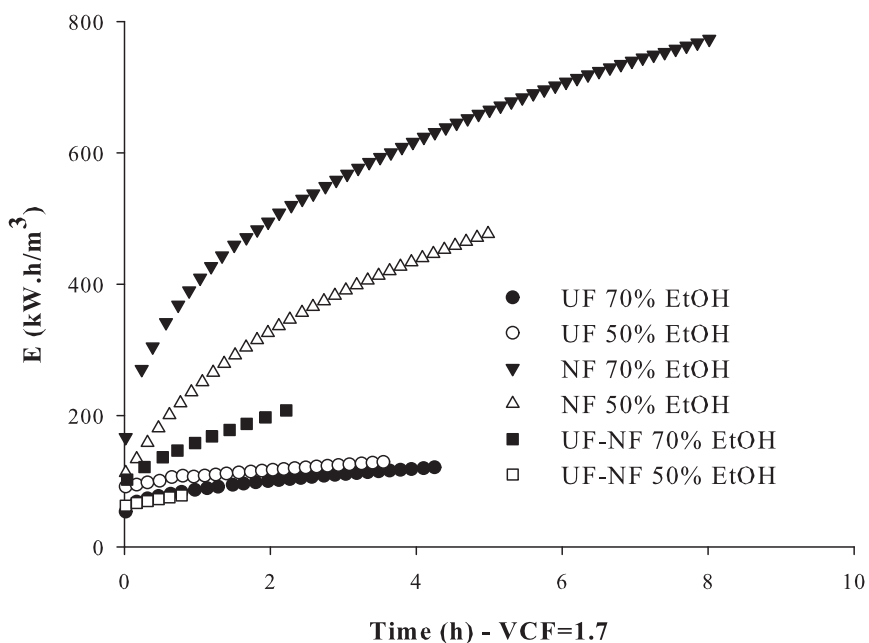

(a)

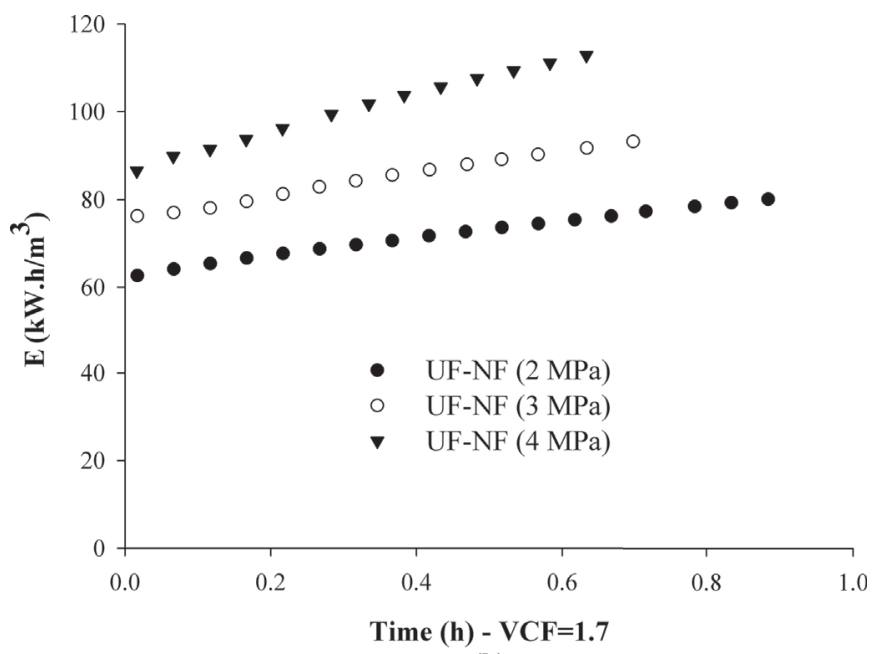

(b)

Fig. 7. Prediction of energy consumption of UF, NF and UF-NF membrane processes of hydroalcoholic extracts from graviola leaves with $50 \%$ and $70 \% \mathrm{EtOH}$ as a function of time.

No significant differences in retention coefficients with pressure variation $(\mathrm{p} \leq 0.05)$ were observed, as shown in Table 6 . Combined processes exhibited high retention coefficients, but smaller than those obtained in direct filtrations. This is probably due to cake formation, which was considerably higher in the direct processes. Once the cake is formed, it acts as a selective layer, causing a greater retention of the compounds.

The increment in pressure led to a decrease in the process time as a consequence of an increase in the permeate flux, as expected in NF processes (Table 6). Average fluxes of processes carried out at 3 and $4 \mathrm{MPa}$ were significantly higher $(\mathrm{p} \leq 0.05)$ than those performed at $2 \mathrm{MPa}$, and the flux decline for the three evaluated pressures was moderate, with no significant differences between processes.

\subsubsection{Topography of membranes - AFM}

The roughness of NF membranes after UF at 2, 3 and $4 \mathrm{MPa}$ is shown in Fig. 6. In comparison with the result shown in Fig. 4, the roughness of these membranes was much lower than those observed in the direct NF. These results suggest that the use of ultrafiltration as a previous step to the concentration process of the extracts can increase the useful life of nanofiltration membranes.

In Fig. 6 we can observe also an increase in roughness values with the increase of pressure. This behavior is consistent with the mass transfer phenomena and is indicative of the non-occurrence of compaction on the membrane surface in the range of tested pressures.

\subsection{Energy consumption}

A prediction of the energy consumption of direct and combined systems was made according to Equation (6) in order to select the more productive filtration strategy for the hydroalcoholic extracts from graviola leaves in terms of yield and energy. Results for energy consumption are shown in Fig. 7(a) and (b).

As expected, UF processes conducted at $0.7 \mathrm{MPa}$ had a significantly lower energy consumption compared to the NF processes. For both NF direct and combined processes, extracts with $70 \% \mathrm{EtOH}$ spent much more energy than those with $50 \% \mathrm{EtOH}$. There were not significant differences for UF processes. Extracts with 70\% EtOH spent about $62 \%$ more energy than extracts with $50 \% \mathrm{EtOH}$ in the direct processes, and 1.6 times more time to achieve the same VCF (1.7). Such difference was about 38\% and 2.6 times more time for UF-NF processes (Table 7). With the use of combined processes (UF$\mathrm{NF}$ done sequentially) there was energy saving of approximately $43 \%$ compared to the application of direct NF, $209.7 \mathrm{kWh} / \mathrm{m}^{3}$ versus $481.1 \mathrm{kWh} / \mathrm{m}^{3}$ for extracts with $50 \% \mathrm{EtOH}$, and $332.5 \mathrm{kWh} / \mathrm{m}^{3}$ versus $773.2 \mathrm{kWh} / \mathrm{m}^{3}$ for extracts with $70 \% \mathrm{EtOH}$.

The low permeate fluxes obtained in the filtrations of extracts containing $70 \% \mathrm{EtOH}$ resulted in an increased energy consumption. In UF-NF processes with $50 \% \mathrm{EtOH}$, the energy consumption was $17 \%$ and $40 \%$ higher for processes performed at 3 and $4 \mathrm{MPa}$, respectively, than for the ones carried out at $2 \mathrm{MPa}$ (Table 7).

Energy consumption increased with pressure (Fig. 7b). The average energy consumption was $80.41 \mathrm{KWh} / \mathrm{m}^{3}$ for processes performed at $2 \mathrm{MPa}, 93.1 \mathrm{KWh} / \mathrm{m}^{3}$ at $3 \mathrm{MPa}$ and $113.4 \mathrm{KWh} / \mathrm{m}^{3}$ at $4 \mathrm{MPa}$. These results are important when considering the scale-up to commercial units. Other costs inherent to the process should also be considered, such as the energy needed to reduce the particle size of the leaves prior to extraction and solvent recovery.

\section{Conclusion}

Combined UF-NF processes proved to be effective in separating phenolics from hydroalcoholic extracts from graviola leaves to obtain enriched fractions. This sequential design resulted in higher fluxes of NF, the fluxes increased almost seven times for extracts with $50 \% \mathrm{EtOH}$, and almost three times for extracts with $70 \% \mathrm{EtOH}$ when compared to direct processes. The retention of the permeated

Table 7

Energy consumption of direct and combined membrane process to achieve a VCF $=1.7$.

\begin{tabular}{|c|c|c|c|c|c|c|}
\hline Direct process (2.0 MPa) & $\mathrm{E}\left(\mathrm{kWh} / \mathrm{m}^{3}\right)$ & Time $^{a}(h)$ & Combined process & & $\mathrm{E}\left(\mathrm{kWh} / \mathrm{m}^{3}\right)$ & Time $^{\mathrm{a}}(\mathrm{h})$ \\
\hline UF 50\% EtOH & $129.3 \pm 3.8$ & 3.6 & UF-NF 50\% EtOH & $2.0 \mathrm{MPa}$ & $80.4 \pm 1.9$ & 0.9 \\
\hline UF 70\% EtOH & $121.8 \pm 6.2$ & 4.3 & & $3.0 \mathrm{MPa}$ & $93.1 \pm 0.3$ & 0.7 \\
\hline NF 50\% EtOH & $481.1 \pm 2.2$ & 5.1 & & $4.0 \mathrm{MPa}$ & $113.4 \pm 0.7$ & 0.6 \\
\hline NF 70\% EtOH & $773.2 \pm 5.3$ & 8.0 & UF-NF 70\% EtOH & $2.0 \mathrm{MPa}$ & $210.7 \pm 5.4$ & 2.3 \\
\hline
\end{tabular}

a Process time. 
compounds on the UF membrane which were concentrated by nanofiltration was higher than $75 \%$ for extracts with 50 or $70 \%$ ethanol indicating the potential of this strategy, in detriment of the direct NF process.

The highest ethanol concentration in the extracts negatively affected the flux permeation performance, but had little influence on rejecting the compounds of interest. The pressure variation in the NF step conducted with extracts containing 50\% EtOH also did not result in significant differences in the retention of bioactive compounds.

\section{Acknowledgements}

The authors give thanks to Iolla Farm for providing the graviola leaves for this study; to Engineering Laboratory Processes of Food Engineering Department (FEA-UNICAMP) for granting the use of the membrane system and Mastersizer equipment (Process EMU 2009/ 54137-1), to the Fruit, Vegetables and Sugar Products Laboratory of Food Technology Department (FEA-UNICAMP) for all physical infrastructure and financial support to carry out the experiments and analyses, and finally to CAPES and CNPq for the scholarships support.

\section{Appendix A. Supplementary data}

Supplementary data related to this article can be found at https://doi.org/10.1016/j.jclepro.2017.11.062.

\section{References}

ADAB, 2016. Agência de Defesa Agropecuária da Bahia. Personal communication. http://www.adab.ba.gov.br/.

Alles, M.J.L., Tessaro, I.C., Noreña, C.P.Z., 2015. Concentration and purification of Yacon (Smallanthus sonchifolius) root fructooligosaccharides using membrane technology. Food Technol. Biotechnol. 53 (2), 190-200. https://doi.org/10.17113/ ft b.53.02.15.3766.

Almela, L., Sánchez-Muñoz, B., Fernández-López, J.A., Roca, M.J., Rabe, V., 2006. Liquid chromatographic-mass spectrometric analysis of phenolics and free radical scavenging activity of rosemary extract from different raw material. J. Chromatogr. A 1120, 221-229. https://doi.org/10.1016/j.chroma.2006.02.056.

Azmir, J., Zaidul, I.S.M., Rahman, M.M., Sharif, K.M., Mohamed, A., Sahena, F., Jahurul, M.H.A., OMAR, A.K.M., 2013. Techniques for extraction of bioactive compounds from plant materials: a review. J. Food Eng. 117, 426-436. https:// doi.org/10.1016/j.jfoodeng.2013.01.014.

Bhanushali, D., Kloos, S., Kurth, C., Bhattacharyya, D., 2001. Performance of solventresistant membranes for non-aqueous systems: solvent permeation results and modeling. J. Memb. Sci. 189, 1-21. https://doi.org/10.1016/S0376-7388(01) 00356-8.

Boussu, K., Van der Bruggen, B., Volodin, A., Snauwaert, J., Van Haesendonck, C., Vandecasteele, C., 2005. Roughness and hydrophobicity studies of nanofiltration membranes using different modes of AFM. J. Colloid Interface Sci. 286, 632-638. https://doi.org/10.1016/j.jcis.2005.01.095.

Boussu, K., Belpaire, A., Volodin, A., Van Haesendonck, C., Van der Meeren, P., Vandecasteele, C., Van der Bruggen, B., 2007. Influence of membrane and colloid characteristics on fouling of nanofiltration membranes. J. Memb. Sci. 289, 220-230. https://doi.org/10.1016/j.memsci.2006.12.001.

Cassano, A., Conidi, C., Giorno, L., Drioli, E., 2013. Fractionation of olive mill wastewaters by membrane separation techniques. J. Hazard. Mater. 248-249. https://doi.org/10.1016/j.jhazmat.2013.01.006, 185-193.

Cheryan, M., Merin, U., 1981. Ultrafiltration membranes and applications. In: Hallstrom, B., Lund, D.B., Tragardh, C. (Eds.), Fundamentals and Application of Surface Phenomenon Associated with Fouling and Cleaning in Food Processing. Lund University Press, Lund, Sweden.

Chipurura, B., Muchuweti, M., Manditseraa, F., 2010. Effects of thermal treatment on the phenolic content and antioxidant activity of some vegetables. Asia Pac J. Clin. Nutr. 2 (3), 93-100. https://doi.org/10.3923/ajcn.2010.93.100.

Cissé, M., Vaillant, F., Pallet, D., Dornier, M., 2011. Selecting ultrafiltration and nanofiltration membranes to concentrate anthocyanins from roselle extract (Hibiscus sabdariffa L.). Food Res. Int. 44 (9), 2607-2614. https://doi.org/10.1016/ j.foodres.2011.04.046.

Conidi, C., Cassano, A., Drioli, E., 2012. Recovery of phenolic compounds from orange press liquor by nanofiltration. Food Bioprod. Process 90, 867-874. https:// doi.org/10.1016/j.fbp.2012.07.005.

Cruz, A.P.G., Sousa, C.G.S., Torres, A.G., Freitas, S.P., Cabral, L.M.C., 2013. Recuperação de compostos bioativos a partir do bagaço de uva. Rev. Bras. Frutic. 35 (4),
1147-1157. https://doi.org/10.1590/S0100-29452013000400026.

Dávalos, A., Gómez-Cordovés, C., Bartolomé, B., 2004. Extending applicability of the oxygen radical absorbance capacity (ORAC-Fluorescein) assay. J. Agric. Food Chem. 52, 48-54. https://doi.org/10.1021/jf0305231.

El-Abbassi, A., Kiai, H., Raiti, J., Hafidi, A., 2014. Application of ultrafiltration for olive processing wastewaters treatment. J. Clean. Prod. 65, 432-438. https://doi.org/ 10.1016/j.jclepro.2013.08.016.

Ferrer-Polonio, E., Carbonell-Alcaina, C., Mendoza-Roca, J.A., Iborra-Clar, A., ÁlvarezBlanco, S., Bes-Piá, A., Pastor-Alcaniz, L., 2017. Brine recovery from hypersaline wastewaters from table olive processing by combination of biological treatment and membrane technologies. J. Clean. Prod. 142, 1377-1386. https://doi.org/ 10.1016/j.jclepro.2016.11.169.

Freitas, A.L.G.E., 2012. de. Caracterização da produção e do mercado da graviola (Annona muricata L.) no Estado da Bahia. Universidade Estadual do Sudoeste da Bahia, Vitória da Conquista, p. 108 f. Dissertação (Mestrado em Agronomia Fitotecnia).

Gajalakshmi, S., Vijayalakshmi, S., Devi, R.V., 2012. Phytochemical and pharmacological properties of Annona muricata: a review. Int. J. Pharm. Pharm. Sci. 4, 3-6.

Gavamukulya, Y., Abou-Elella, F., Wamunyokoli, F., AEI-Shemy, H., 2014. Phytochemical screening, anti-oxidant activity and in vitro anticancer potential of ethanolic and water leaves extracts of Annona muricata (Graviola). Asian Pac. J. Trop. Med. 7 (Suppl. 1), S355-S363. https://doi.org/10.1016/S1995-7645(14) 60258-3.

Geens, J., Peeters, K., Van der Bruggen, B., Vandecasteele, C., 2005. Polymeric nanofiltration of binary water-alcohol mixtures: influence of feed composition and membrane properties on permeability and rejection. J. Memb. Sci. 255, 255-264. https://doi.org/10.1016/j.memsci.2005.01.039.

Giacobbo, A., Meneguzzi, A., Bernardes, A.M., de Pinho, M.N., 2017. Pressure-driven membrane processes for the recovery of antioxidant compounds from winery effluents. J. Clean. Prod. 155, 172-178. https://doi.org/10.1016 j.jclepro.2016.07.033.

Hermia, J., 1982. Constant pressure blocking filtration laws-apliccation to powerlaw non-newtonian fluids. Chem. Eng. Res. Des. 60, 183-187.

Jönsson, Ann-Sofi, Wallberg, O., 2009. Cost estimates of kraft lignin recovery by ultrafiltration. Desalination 237 (1), 254-267. https://doi.org/10.1016/ j.desal.2007.11.061.

La Scalia, G., Micale, R., Cannizzaro, L., Marra, F.P., 2017. A sustainable phenolic compound extraction system from olive oil mill wastewater. J. Clean. Prod. 142 3782-3788. S0959652616316973.

Lemos, E.E.P., 2014. A produção de anonáceas no Brasil. Rev. Bras. Frutic. 36, 77-85. https://doi.org/10.1590/S0100-29452014000500009.

Li, J., Chase, H.A., 2010. Applications of membrane techniques for purification of natural products. Biotechnol. Lett. 32, 601-608. https://doi.org/10.1007/s10529009-0199-7.

Machado, M.T.C., Mello, B.C.B.S., Hubinger, M.D., 2013. Study of alcoholic and aqueous extraction of pequi (Caryocar brasiliense Camb.) natural antioxidants and extracts concentration by nanofiltration. J. Food Eng. 117 (4), 450-457. https://doi.org/10.1016/j.jfoodeng.2012.12.007.

Machado, A.R.T., Lage, G.A., Medeiros, F.S., Filho, J.D.S., Pimenta, L.P.S., 2015. Total $\alpha, \beta$-unsaturated- $\gamma$-lactone acetogenins in Annona muricata by proton NMR spectroscopy. Appl. Mag. Res. 46, 153-160.

Matos, F.J.A., Lorenzi, H., 2008. Plantas Medicinais no Brasil - Nativas e Exóticas - $2^{\text {a }}$ Edição - Nova. Instituto Plantarum de Estudos da Flora, Odessa, SP.

Mohammad, A.W., Teow, Y.H., Ang, W.L., Chung, Y.T., Oatley-Radcliffe, D.L., Hilal, N. 2015. Nanofiltration membranes review: recent advances and future prospects. Desalination 356, 226-254.

Moraes, I.V.M., Ribeiro, P.R.V., Schmidt, F.L., Canuto, K.M., Zocolo, G.J., Brito, E.S., Luo, R., Richards, K.M., Tran, K., Smith, R.E., 2016. UPLC-QTOF-MS and NMR analyses of graviola (Annona muricata) leaves. Rev. Bras. Farmacogn. 26, 174-179. https://doi.org/10.1016/j.bjp.2015.12.001.

Murakami, A.N.N., Amboni, R.D.M.C., Prudêncio, E.S., Amante, E.R., Zanotta, L.M. Maraschin, M., Petrus, J.C.C., Teófilo, R.F., 2011. Concentration of phenolic compounds in aqueous mate (Ilex paraguariensis A. St. Hil) extract through nanofiltration. LWT - Food Sci. Technol. 44 (10), 2211-2216. https://doi.org/ 10.1016/j.lwt.2011.06.002.

Nawwar, M., Ayoub, N., Hussein, S., Hashim, A., El-Sharawy, R., Wende, K., Harms, M., Lindequist, U., 2012. A flavonol triglycoside and investigation of the antioxidant and cell stimulating activities of Annona muricata Linn. Arch. Pharm. Res. 5, 761-767. https://doi.org/10.1007/s12272-012-0501-4.

Nghiem, L.D., Hawkes, S., 2007. Effects of membrane fouling on the nanofiltration of pharmaceutically active compounds (PhACs): mechanisms and role of membrane pore size. Sep. Purif. Technol. 57, 176-184. https://doi.org/10.1016/ j.seppur.2007.04.002.

Oatley-Radcliffe, D.L., Williams, S.R., Ainscough, T.J., Lee, C., Johnson, D.J., Williams, P.M., 2015. Experimental determination of the hydrodynamic forces within nanofiltration membranes and evaluation of the current theoretical descriptions. Sep. Purif. Technol. 149, 339-348. https://doi.org/10.1016/ j.seppur.2015.05.041.

Penha, F.M., Rezzadori, K., Proner, M.C., Zin, G., Fogaça, L.A., Petrus, J.C.C., De Oliveira, J.V., Di Luccio, M., 2015. Evaluation of permeation of macauba oil and n-hexane mixtures through polymeric commercial membranes subjected to different pre-treatments. J. Food Eng. 155, 79-86. https://doi.org/10.1016/ j.jfoodeng.2015.01.020.

Pinto, P.C.R., Mota, I.F., Loureiro, J.M., Rodrigues, A.E., 2014. Membrane performance 
and application of ultrafiltration and nanofiltration to ethanol/water extract of Eucalyptus bark. Sep. Purif. Technol. 132, 234-243. https://doi.org/10.1016 j.seppur.2014.04.042.

Prudêncio, A.P.A., Prudêncio, E.S., Amboni, R.D.M.C., Murakami, A.N.N. Maraschin, M., Petrus, J.C.C., Ogliari, P.J., Leite, R.S., 2012. Phenolic composition and antioxidant activity of the aqueous extract of bark from residues from mate tree (Ilex paraguariensis St. Hil.) bark harvesting concentrated by nanofiltration. Food Bioprod. Process 90, 399-405. https://doi.org/10.1016/j.fbp.2011.12.003.

Rabelo, R.S., Machado, M.T.C., Martínez, J., Hubinger, M.D., 2016. Ultrasound assisted extraction and nanofiltration of phenolic compounds from artichoke solid wastes. J. Food Eng. 178, 170-180. https://doi.org/10.1016/ j.jfoodeng.2016.01.018.

Re, R., Pellegrini, N., Proteggente, A., Pannala, A., Yang, M., Rice-evans, C., 1999. Antioxidant activity applying an improved ABTS radical cation decolorization assay. Free Radic. Biol. Med. 26 (9/10), 1231-1237. https://doi.org/10.1016/ S0891-5849(98)00315-3.

Romero-Dondiz, E.M., Almazán, J.E., Rajal, V.B., Castro-Vidaurre, E.F., 2016. Comparison of the performance of ultrafiltration and nanofiltration membranes for recovery and recycle of tannins in the leather industry. J. Clean. Prod. 135, 71-79. https://doi.org/10.1016/j.jclepro.2016.06.096.

Rufino, M.S.M., Alves, R.E., Brito, E.S., Morais, S.M., Sampaio, C.G., Pérez-Jiménez, J., Saura-Calixto, F.D., 2007. Metodologia Científica: Determinação da atividade antioxidante total em frutas pela captura do radical ABTS.+. Comunicado Técnico (Embrapa Agroindústria Tropical).

São José, A.R., Pires, M. de M., Freitas, A.L.G.E., Ribeiro, D.P., Perez, L.A.A., 2014.
Actuality and perspectives of Annonaceous in the world. Rev. Bras. Frutic. 36, 86-93. https://doi.org/10.1590/S0100-29452014000500010.

Singleton, V.L., Orthofer, R., Lamuela-raventós, R.M., 1999. Analysis of total phenols and others oxidation substrates and antioxidants by means of Folin-Ciocalteu reagent. Methods Enzymol. 299, 152-178. https://doi.org/10.1016/S00766879(99)99017-1.

Tabart, J., Kevers, C., Sipel, A., Pincemail, J., Defraigne, J.-O., Dommes, J., 2007. Optimisation of extraction of phenolics and antioxidants from black currant leaves and buds and of stability during storage. Food Chem. 105 (3), 1268-1275. https://doi.org/10.1016/j.foodchem.2007.03.005.

Tylkowski, B., Trusheva, B., Bankova, V., Giamberini, M., Peev, G., Nikolova, A., 2010. Extraction of biologically active compounds from propolis and concentration of extract by nanofiltration. J. Memb. Sci. 348, 124-130. https://doi.org/10.1016/ j.memsci.2009.10.049.

Weinwurm, F., Drljo, A., Waldmüller, W., Fiala, B., Niedermayer, J., Friedl, A., 2016. Lignin concentration and fractionation from ethanol organosolv liquors by ultra- and nanofiltration. J. Clean. Prod. 136, 62-71. https://doi.org/10.1016/ j.jclepro.2016.04.048.

Wong, P.C.Y., Kwon, Y.-N., Criddle, C.S., 2009. Use of atomic force microscopy and fractal geometry to characterize the roughness of nano-, micro-, and ultrafiltration membranes. J. Memb. Sci. 340, 117-132. https://doi.org/10.1016/ j.memsci.2009.05.018.

Yang, X.J., Livingston, A.G., dos Santos, L.F., 2001. Experimental observations of nanofiltration with organic solvents. J. Memb. Sci. 190, 45-55. https://doi.org/ 10.1016/S0376-7388(01 )00392-1. 